\title{
Petrophysical Analysis of the Mpapai Well Logs in the East Pande Exploration Block, Southern Coast of Tanzania: Geological Implication on the Hydrocarbon Potential
}

\author{
Aneth L. Lyaka, Gabriel D. Mulibo* \\ Department of Geology, University of Dar es Salaam, Dar es Salaam, Tanzania \\ Email: *gmbelwa@yahoo.com
}

How to cite this paper: Lyaka, A.L. and Mulibo, G.D. (2018) Petrophysical Analysis of the Mpapai Well Logs in the East Pande Exploration Block, Southern Coast of Tanzania: Geological Implication on the Hydrocarbon Potential. Open Journal of Geology, 8, 781-802.

https://doi.org/10.4236/ojg.2018.88046

Received: June 5, 2018

Accepted: August 1, 2018

Published: August 3, 2018

Copyright $\odot 2018$ by authors and Scientific Research Publishing Inc. This work is licensed under the Creative Commons Attribution International License (CC BY 4.0).

http://creativecommons.org/licenses/by/4.0/

\begin{abstract}
This study presents results of log analysis from Mpapai well, which is located in the East Pande Block, southern coast of Tanzania. The study aimed at assessing the hydrocarbon potential of lithological units encountered during drilling of Mpapai well. To achieve the general objective, suites of wire-line logs from Mpapai well were used for the analysis. Based on wire-line logs, three types of lithology were identified which include sandstone, shale and limestone. Seven sandstone bodies marked as MpapaiA, B, C, D, E, F and G were identified with their tops and bases at the depth interval from $3004 \mathrm{~m}$ to $4008 \mathrm{~m}$. Four zones among seven sandstones bodies marked as MpapaiB, E, F and MpapaiG were identified as reservoir zones. Computed petrophysical parameters for the four reservoir zones gave an average total porosity ranging from $14 \%$ to $21 \%$ with low permeability in the range of $3.92 \mathrm{mD}$ to $13.67 \mathrm{mD}$. The low permeability indicates that the reservoir sand bodies are impermeable, that might have been affected by the geology of the area where high content of clay minerals reduces permeability due to filling in open spaces. The fluid type defined in the reservoir zones is basically water with high saturation greater than $75 \%$, which indicates that the proportion of void space occupied by water is high, consequently low hydrocarbon saturation and production. Despite of fair to good porosity, the low permeability and high-water saturation indicate that the quality of Mpapai prospect is poor.
\end{abstract}

\section{Keywords}

Lithology, Hydrocarbon, Mpapai, Reservoir, Geology 


\section{Introduction}

Southern coastal basins of Tanzania are located in the southern tip of the Somali basin, which is connected to the Natal basin in South Africa through the Mozambique Channel [1]. These basins evolved from Permian as the result of rifting and drifting of Gondwana, which resulted in the fragmentation of Eastern and Western Gondwana as well as the opening of Indian Ocean. These tectonic movements occurred along the strike-slip fault currently known as Davie Fracture Zone (Figure 1) [2] [3]. These movements also facilitated the development of the present Tanzania Coastal Basin encompassing a narrow belt along the mainland.

The East Pande Block belongs to Pande Formation (Late Cretaceous to Early Oligocene) of the Kilwa Group that consists of both onshore and offshore parts of the Southern coastal basins of Tanzania. Other formations forming the Kilwa group are the Nangurukuru (Late Cretaceous to Paleocene), Kivinje (Paleocene to Lower Eocene) and Masoko (Middle Eocene) formations [4]. Mpapai well is the exploration well located on one of the shallow offshore Tanzania basins within the East Pande Block. The well was drilled from $681.3 \mathrm{~m}$ of water depth

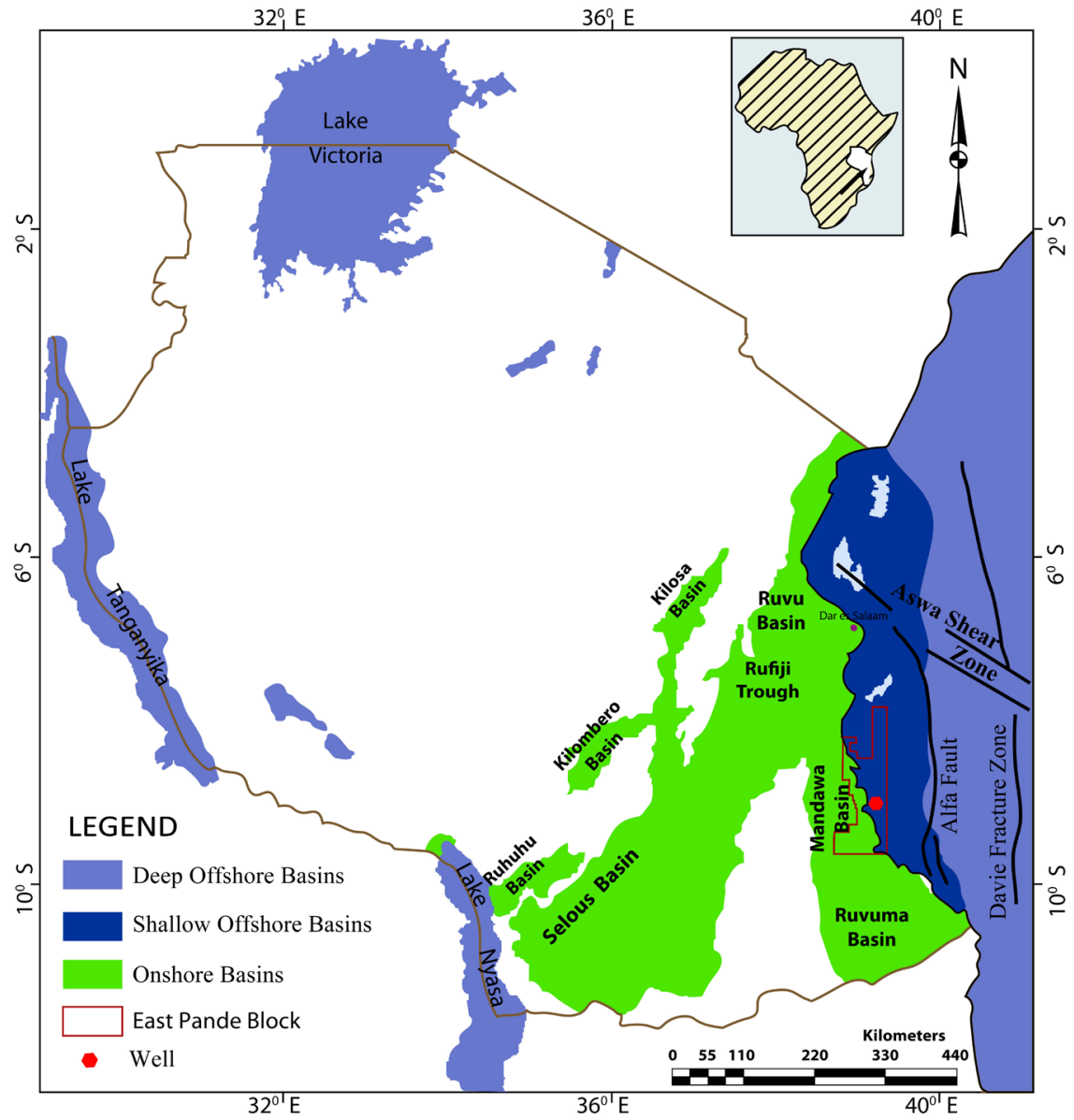

Figure 1. The map of Tanzania showing location of the East Pande Block (maroon polygon) and Mpapai well represented by red dot, (modified from [7]). 
to a total depth of $4153 \mathrm{~m}$. The preliminary petrophysical analysis of well logs indicated that gas traces were encountered in the upper strata of Mpapai well. The presence of water and gas traces encountered at $781 \mathrm{~m}$ of water depth suggests that the East Pande Block have possible petroleum system. This suggests that the petroleum system in the East Pande Block contains matured source rock somewhere in the basin. Despite the presence of hydrocarbon traces within the Mpapai well, little is documented about petrophysical properties of reservoir rocks. Lithological units that constitute the East Pande Block are not well known. In addition, the sequence and thickness of sedimentary units, which are potential for petroleum system, are also not well established.

Petrophysical analysis of well logs is one among the most useful and important tools for reservoir rock characterization. It helps to define physical characteristics of rocks such as lithology, porosity, permeability and fluid saturation. The analysis is also useful in identifying potential reservoir intervals, distinguishing the type of fluid in a reservoir and estimating hydrocarbon reserves [5] [6]. This study therefore aims at using well logs data to characterize sedimentary units of Mpapai well and to delineate potential reservoir formations based on petrophysical properties in order to assess the hydrocarbon potential of lithological units encountered during drilling of Mpapai well by using well logs data (gamma ray log, neutron porosity log, bulk density log, PEF values and resistivity logs).

\section{Geology and Tectonic Setting}

\subsection{General Geological Setting}

The East Pande Exploration Block is one among the south-eastern Tanzania coastal basin located along the passive continental margins of western Indian Ocean developed on the Precambrian Pan-African basement [8]. Stratigraphically, the East Pande formation forms the upper part of the Kilwa group, which developed during the period of tectonic stability. The group can be broadly divided into lower and upper formations; the lower two (Nangurukuru and Kivinje) being predominantly claystone, while the upper two (Masoko and Pande) are unconsolidated clays [9].

The bedrock of the Kilwa Peninsula area is composed of Upper Cretaceous to Lower Miocene claystone and clays, where the Late Campanian to Middle Eocene aged clays are assigned to the Kilwa Group [4]. The clays are overlain by marked angular unconformity of Lower Miocene clays [8] that are probably locally reworked and re-deposited Kilwa Group. Subordinate secondary lithology such as thin, "ribbon" limestone and sandstones occur throughout the Kilwa Group at various stratigraphic intervals [4]. The Kilwa Masoko Fault (KMF) which trends along the NNW to SSE has brought Oligocene clays against Middle Eocene Masoko Formation clays; however, the clays east of the fault were previously assigned to the Neogene [4]. It is also possible that these clays are actually Oligocene Pande Formation clays, which have undergone recent carbonate 
dissolution from percolating rainwaters, removing the diagnostic biozone [9].

The East Pande formation (Late Cretaceous to Early Oligocene) (Figure 2) is uniformly composed of greenish black to dark greenish grey clay or muddy clays developing a mild shaly parting. Fine to very fine angular quartz sandy parting also occur throughout the clays in the upper horizons which have occasionally developed a carbonate cement to produce very thin, sandy calcarenite beds with poorly cemented tops and bases [4].

\subsection{Tectonic Setting}

The geology of the area is strongly affected by two-stage break-up of Gondwana,

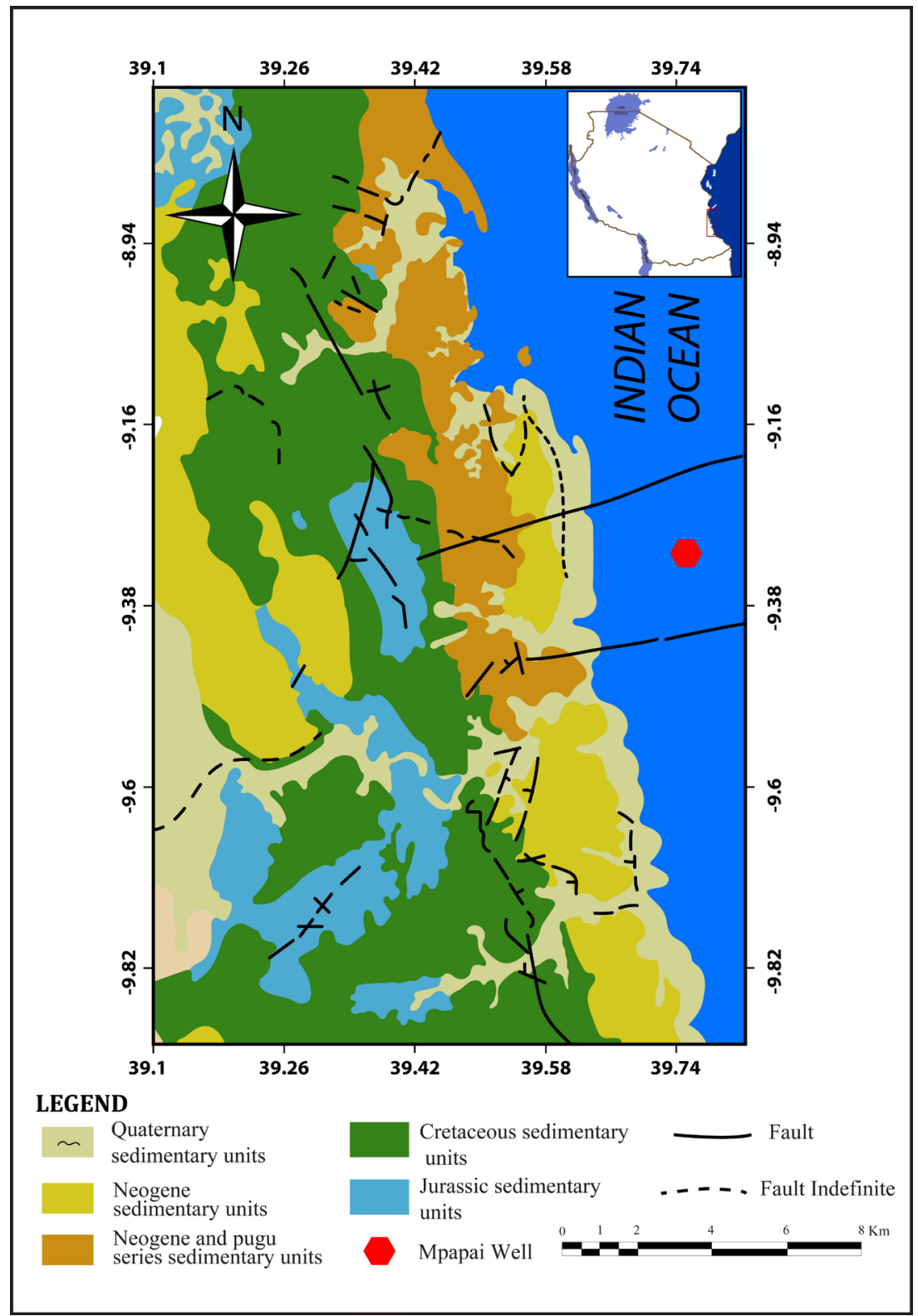

Figure 2. Geological map of the East Pande Block showing different rock types and structures, predominantly faults which trend in various directions (modified from [8]). 
which began at about $300 \mathrm{Ma}$ [2]. An initial rifting phase from 300 to $205 \mathrm{Ma}$ created extended rift systems across the continent which filled with thick siliciclastic and carbonate sediments of the Karoo Group. The second phase from about $205 \mathrm{Ma}$ to $157 \mathrm{Ma}$ marked the actual fragmentation of Gondwana and was accompanied by the extrusion of extensive flood basalts. From about $157 \mathrm{Ma}$, active sea-floor spreading in the Western Somalia and Mozambique Channel Basins separated Gondwana into East (Antarctica, India and Sri Lanka, Madagascar, Seychelles and Australia) and West (Africa and South America) blocks. This also resulted in the divergence of the two blocks concentrated along the major transform zones of the Davie Ridge, Mozambique Escarpment and Explore Escarpment in Antarctica [2] [10].

The rifting and spreading was accompanied by a major marine transgression onto the passive continental margins of both West and East Gondwanan blocks. In Tanzania, this resulted in thick Upper Jurassic and Lower Cretaceous sedimentation in a series of marginal basins, which include the Mandawa and Ruvuma Basins. By the end of the Early Cretaceous, the axis of spreading had jumped east of Madagascar which resulted in a period of stabilization along the East African margin. A Late Cretaceous transgression resulted in widespread deep-water clay and mud facies accumulating in offshore basins, and similar conditions continued into the Paleogene. Thick clay deposits are particularly well developed along coastal Tanzania. At about $35 \mathrm{Ma}$ the current East African Rift system had been initiated and was followed by renewed tectonic movement along the Davie and Mozambique submarine ridges [2].

\subsection{Sequence Stratigraphy of the Offshore Tanzania}

The present sequence stratigraphic framework and architecture of offshore Tanzania basins, spanning the post break-up Jurassic to Neogene has been well established by (Figure 3) [11]. The post-rift succession comprises a number of unconformity-bound stratigraphic sequences, which can be grouped into 8 megasequences (MS). The Lower-Middle Jurassic deposits of the rift basins, which record the rifting and separation of Madagascar from Africa, are assigned to megasequence J1. Marine transgression in the upper part of MS J1 is characterized by the deposition of shallow-marine carbonates and associated siliciclastic of Bajocian-Bathonian age, which overstep the syn-rift deposits onto basement in some areas. In exploration Block 1, folding and inversion of the syn-rift deposits occurred prior to the widespread Callovian marine transgression, which marks the base of MS J2 (Callovian-Tithonian) and accompanied the subsequent southward drift of Madagascar along the Davie Fracture Zone.

The stratigraphy of the East Pande exploration Block is defined by Megasequence K1 to Pg2 in which, Megasequence K1 (Berriasian-Aptian) is not well resolved, this is due to limited well penetrations offshore for seismic calibration, and poor biostratigraphic dating. The K2 Megasequence (Early Albian-Early Campanian) records the development of a thick, muddy slope characterized by 


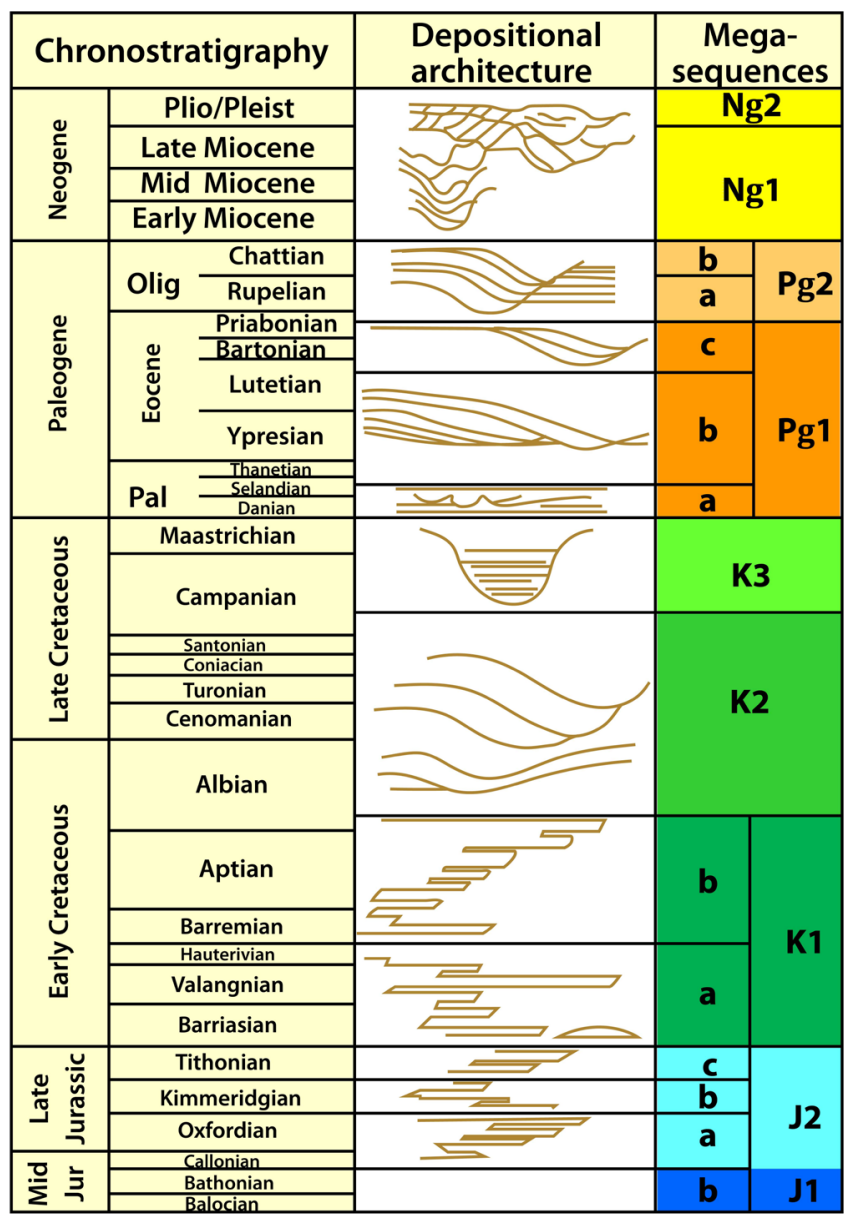

Figure 3. Sequence stratigraphy and depositional architecture of offshore Tanzania (modified from [11]).

the presence of long-lived slope valley systems in the architecture of Tanzania. MS K3 records the complete infilling of canyons in Mid-Late Campanian times, by back stepping, ponded sheet-systems, comprising high-density turbidity and hybrid flow deposits. The Base Tertiary unconformity marks another major change in depositional style at the base of Megasequence Pg1 (Paleocene-Eocene). MS Pg1 is divided into three parts based on changes in depositional style and unconformities recorded in offshore well data. Ng1 Megasequence is characterized by the onset of major slope failures, which result in plugging, and disruption of the slope channel systems. A renewed phase of slope failure and extensive fan deposition represents the Pliocene-Recent (Ng2 Megasequence) and numerous deep canyons still characterize the slope today.

\section{Material and Methods}

The study accomplished the objectives using well log data from Mpapai well provided by Tanzania Petroleum Development Company (TPDC). Well logs include gamma ray log, photeolectric factors (PEF), resistivity logs which include shallow, medium and deep resistivity, density log, neutron-porosity log and son- 
ic log. Well logs from Mpapai well were used to analyze the petrophysical properties of the reservoir rocks. Both qualitative and quantitative interpretations were conducted using different well log data. The wireline logs used were gamma ray log, resistivity logs, photoelectric effect log (PEF), sonic log, neutron and density log. Log interpretation was conducted using Techlog software version 2013.4.0.1.

\subsection{Lithology Identification}

The identification of lithology is fundamental to all reservoir characterization because the physical and chemical properties of the rock that holds hydrocarbons and/or water affect the response of every tool used to measure reservoir properties [12]. Understanding reservoir lithology is the foundation from which all other petrophysical calculations are made. The best logs for lithology identification are those that are most influenced by rock properties and least influenced by fluid properties [13]. In this study, lithology across Mpapai well were identified using gamma ray (GR) log, photoelectric factors (PEF), neutron-density combination and cross plot as described in the following sub sections.

\subsubsection{Lithological Identification from Gama Ray Log}

Identification of lithology from gamma ray log was done by reading API values on the gamma ray curve which ranges from 0 to $150 \mathrm{API}$ where the sand/shale baseline was inserted at 75 API in order to differentiate the two lithologies (sand and shale). Therefore, all formations with gamma ray values less than 75 API were classified as sandstone, while those with gamma ray values greater than 75 API were classified as shale.

\subsubsection{Lithological Identification from Photoelectric Factor}

In this study, classification of lithology was based on the values given in Table 1 [6], which shows the common lithology with their photoelectric values. Values were obtained by taking the average values from log curve across each lithology.

\subsubsection{Lithological Identification from Neutron-Density Combination}

Neutron and density logs were sketched together in the same track for doing some comparison and the correlation between the two curves leads to better lithology identification. When both the density and neutron logs show lower value, it indicates sandstone formation whereby overlay of the two log curves shows limestone lithology and the increase of neutron and density value indicates shale lithology.

Table 1. Photoelectric parameters for common lithology in sedimentary rock (modified from [6]).

\begin{tabular}{cccccc}
\hline Lithology & Sandstone & Dolomite & Shale & Limestone & Anhydrite \\
\hline PEF value barns/electron & $1.8-2$ & $3.14-4$ & $1.8-6$ & 5 & 5 \\
\hline
\end{tabular}




\subsubsection{Lithological Identification from Neutron-Density Cross plots}

Neutron-density cross plots are easy to use for clean (non-shaly) reservoir rocks. The plots are entered with a bulk density and apparent neutron porosity. A rock type (sandstone, limestone, or dolomite) and a corrected porosity can be read from the cross plot. The neutron-density cross plot was used to determine lithology of Mpapai well by plotting together neutron and density logs and use gamma ray $\log$ for scale. Points were observed to fall into different lithological regions and the interpretation of the lithology (sandstone, carbonate and shale) was based on color legend bar, which is the intensity of gamma rays. The gamma ray intensity represents the amount of concentration of the radioactive elements present in the neutron-density logs, thus giving different types of lithology.

\subsection{Reservoir Identification}

Reservoir is the only zone, which is potential for economic interest because it contains storage space for fluid (hydrocarbon or water) to accumulate. Thus, must first of all be identified in order to evaluate important parameters suitable for hydrocarbon exploration. Reservoir identification was conducted after the interpretation of various lithology of Mpapai well. The clean (non-shale) formation was marked in different zones as reservoir rocks. Reservoir rocks are defined as subsurface pool of hydrocarbon or water contained in porous or fractured rock formation [6].

Porosity and permeability are the most important physical properties of the reservoir rocks. For rock to be named a reservoir has to be porous and permeable. Sandstone (which covers $62 \%$ of the petroleum reservoir) and Limestone are two sedimentary rocks, which are used as reservoir rocks [5]. A good reservoir rock must be a good porous, permeable and contains hydrocarbon as well. In this study reservoir rock was identified using gamma ray log, resistivity log and neutron-density crossover.

Gamma ray log was used in the identification of reservoir rock based on the fact that, sandstone reservoir exhibits very low radioactivity because of low content of radioactive elements hence have low gamma ray value and the log deflect to the left of shale/sand baseline [12]. Resistivity logs (deep and medium) were also used to identify reservoir zone in the sense that, reservoir zones exhibit relatively higher resistivity values than non-reservoir zones. Based on neutron and density logs, reservoir rock was also marked by the presence of neutron-density crossover, which indicated the presence of fluid.

\subsection{Fluid Identification}

It is very important to identify the type of fluid in a reservoir rock, because reservoirs may contain hydrocarbon (oil and gas), non-hydrocarbon fluid (water) or both. For a reservoir to contain hydrocarbons the zone should be porous with resistivity values higher than those of water-bearing zones [14]. In this study, the resistivity $\log$ and neutron-density log were used to identify hydrocarbon and non-hydrocarbon bearing intervals. Hydrocarbons are poor conductors than 
water, hence show higher resistivity than water bearing interval. Based on neutron and density crossover, gas zone is expected to show wider negative separation due to low density and low hydrogen index of gas. Oil zone is also expected to show relatively low negative separation because of relatively high density and hydrogen index compared to gas. Very low separation is observed in water zone due to higher density and higher hydrogen index in water.

\subsection{Shale Volume Estimation}

The analysis of shale volume was conducted in order to determine the amount of shale or radioactive minerals, contained in the reservoir rock in order to delineate zones of interest. In this study, the volume of shale was estimated using Gamma ray logs and neutron-density methods. The method that gave the minimum value of shale volume was chosen for further estimation of porosity and water saturation in order to minimize the effect of reducing reservoir quality caused by high content of shale volume.

\subsubsection{Shale Volume Estimation from Gamma Ray Logs}

Gamma-ray $\log$ is one of the best tools used for identifying and determining the shale volume. This is principally due to its sensitive response on the radioactive materials, which normally concentrate in the shaly rocks. In this study, the first step to estimate the reservoir's shale volume of Mpapai well from gamma ray logs was to calculate the Gamma Ray Index by using the Dresser Atlas 1979 formula in equation below:

$$
I_{G R}=\frac{G R_{\log }-G R_{\min }}{G R_{\max }-G R_{\min }}
$$

where $I_{G R}$ is the gamma ray index, $G R_{\log }$ is picked log value for each zone, $G R_{\min }$ and $G R_{\max }$ indicate gamma ray values picked in sand and shale base lines respectively.

The gamma ray log has two empirical responses. The linear and non-linear responses, the nonlinear responses are based on geographic area or formation age, which includes the Larionov model [15] for Tertiary (younger) rocks, Steiber [16], Clavier model [17] and Larionov model [15] for older rocks. All non-linear relationships are more optimistic of which they produce a shale volume value lower than that obtained from the linear equation [18]. In this study, the non-linear model was used to calculate shale volume of the reservoir rocks. Reservoir rocks of Mpapai well are of Oligocene age, thus the Larionov model for Tertiary (younger) rocks was used to calculate the volume of shale of the reservoir rock. The shale volume was then calculated from the following formula [19]:

$$
V_{S H}(1969)=0.083 *\left(2^{\left(2 * 3.7 I_{G R}\right)}-1\right)
$$

\subsubsection{Shale Volume Estimation from Neutron-Density Logs}

The separation between neutron and density porosity is a common method for 
calculating shale volume. This method is accurate only when the shaly sand contains pure quartz plus clay minerals. Most sandstones are not pure quartz, but rather may contain other minerals like Micas, siderite, ankerite, and volcanic rock fragments. These minerals are heavier than quartz, which cause excess separation by reducing density porosity and increasing neutron porosity [14]. This method is also inaccurate when the reservoir contains gas, where it affects neutron reading by reducing the neutron porosity value due to low hydrogen index of gas. Despite all these precautions this method was also used to calculate shale volume because of the nature of the geology of the study area that sandstone at Mpapai well consists of clay minerals and fine to very fine angular sand grains [4]. Thus, the method could provide accurate shale volume. The following formula was used to calculate volume of shale from Neutron-Density log as [18]:

$$
V_{s h}=\frac{\phi_{n}-\phi_{d}}{\phi_{N s h}-\phi_{D s h}}
$$

where $V_{s h}=$ Volume of shale, $\phi_{n}=$ Neutron porosity in sand, $\phi_{d}=$ Density porosity in sand, $\phi_{N s h}=$ Neutron porosity in shale portion or adjacent shale and $\phi_{D s h}=$ Density porosity in shale portion or adjacent shale.

\subsection{Porosity Evaluation}

Porosity is very important parameter of the reservoir rock as it is used to describe the amount of open space filled with fluid (hydrocarbon or water). In this study, porosity was calculated from two methods, density log and density-neutron combination logs. The criteria used in classifying porosity are given in Table 2 [20] [21].

\subsubsection{Porosity from Density Log}

Density log is a good method for determining either total or effective porosity in single or multiple mineral fluid-filled reservoirs. The method of estimating porosity from the density requires determining the matrix density $\left(\rho_{m a}\right)$, the density $\log$ reading $\left(\rho_{b}\right)$, and the fluid density $\left(\rho_{f f}\right)$ at the depth of interest. The matrix density is determined by the lithology. Normally, sandstone is $2.65 \mathrm{~g} / \mathrm{cm}^{3}$, limestone is $2.71 \mathrm{~g} / \mathrm{cm}^{3}$, and dolomite is $2.87 \mathrm{~g} / \mathrm{cm}^{3}$ [22], these values were also used in this study. The fluid density is dependent upon the salinity of water and the density of hydrocarbon. Freshwater has a density of $1.0 \mathrm{~g} / \mathrm{cm}^{3}$ and saltwater has approximately $1.1 \mathrm{~g} / \mathrm{cm}^{3}$. Hydrocarbon density can vary widely from $0.05 \mathrm{~g} / \mathrm{cm}^{3}$ for gas at low pressures to nearly $1.0 \mathrm{~g} / \mathrm{cm}^{3}$ for certain oil. A typical value for oil is $0.8 \mathrm{~g} / \mathrm{cm}^{3}$ [23].

Table 2. Porosity values used in the qualitative description of reservoir rocks (Modified from [20] [21]).

\begin{tabular}{ccccccc}
\hline $\begin{array}{c}\text { Average Porosity } \\
(\phi) \text { values }\end{array}$ & $\phi<0.05$ & $0.05<\phi<0.1$ & $0.1<\phi<0.15$ & $0.15<\phi<0.250 .25<\phi<0.30$ & $\phi>0.30$ \\
\hline $\begin{array}{c}\text { Qualitative } \\
\text { description }\end{array}$ & Negligible & Poor & Fair & Good & Very Good & Excellent \\
\hline
\end{tabular}


In this study, the porosity was also determined from density log using the formula below:

$$
\phi=\frac{\rho_{m a}-\rho_{b}}{\rho_{m a}-\rho_{f}}
$$

where $\phi=$ Total porosity, $\rho_{m a}=$ Matrix density (or grain) density $\left(2.65 \mathrm{~g} / \mathrm{cm}^{3}\right)$, $\rho_{b}=$ Formation bulk density from log and $\rho_{f}=$ Fluid density $\left(1.1 \mathrm{~g} / \mathrm{cm}^{3}\right)$.

\subsubsection{Porosity from Neutron-Density Combination}

The combination of neutron and density logs provides a good source of porosity data, especially in formation of complex lithology. Better estimates of porosity are possible with this method than using other tool separately such as density and sonic because inferences about lithology and fluid content can be made. Porosity from Neutron-Density log can be calculated mathematically using the following equation [12]:

$$
\phi_{N-D}=\left(\frac{\phi_{N}^{2}-\phi_{D}^{2}}{2}\right)^{\frac{1}{2}}
$$

where $\phi_{N-D}=$ Neutron-density porosity, $\phi_{N}=$ Neutron porosity and $\phi_{D}=$ Density porosity.

\subsection{Water Saturation Determination}

In this study, two models (the Archie's and Indonesian models) were used to calculate water saturation of the reservoir rocks and results were compared. The Archie's model works well in homogeneous or clean sand reservoir [24] while the Indonesian model work well in both clean sand and shaly sand reservoirs. In clean sand reservoirs both Archie's and Indonesian models provide nearly the same water saturation results, while for shaly sand reservoir Indonesian model provides good water saturation results [25].

\subsubsection{Water Saturation from Archie's Equation Model}

Archie's equation is most famous method for calculating water saturation in clean and Shale free formation. Archie formula is based on the fact that the only conductive material in the formation is salt water; but in a sandy shale formation, ions that are released along with shale are also responsible for conducting electrical current [26]. In this study, Archie's equation was used to calculate water saturation in all reservoir sections, and the results from shaly sand were compared from that of Indonesian model. To calculate water saturation $S_{w}$ from Archie's model, the following equation was used:

$$
S_{w}=\left(\frac{a * R_{w}}{\phi^{m} * R_{t}}\right)^{\frac{1}{n}}
$$

where $S_{w}=$ Water saturation, $R_{w}=$ Formation water resistivity, $\phi=$ Total porosity, $R_{t}=$ True formation resistivity, $a=$ Tortuosity factor, $m=$ Cementation exponent and $n=$ Saturation exponent. 


\subsubsection{Water Saturation from Indonesian Equation}

Water saturation $\left(S_{w}\right)$ results from the formula are comparatively easy to calculate and because it is not a quadratic equation, it gives results that are always greater than zero. Calculation of water saturation by using this method depends on porosity, shale volume and resistivity, water and deep resistivity. Water saturation from Indonesian model is given by the following formula:

$$
S_{w}=\left\{\left[\left(\frac{V_{s h}^{2-V_{s h}}}{R_{s h}}\right)^{\frac{1}{2}}+\left(\frac{\phi_{e}^{m}}{R_{w}}\right)^{\frac{1}{2}}\right]^{2} R_{t}\right\}^{\frac{-1}{n}}
$$

where $V_{s h}=$ Volume of shale, $R_{s h}=$ Resistivity of shale, $S_{w}=$ Water saturation, $\phi_{e}=$ Effective porosity, $R_{w}=$ Water resistivity of formation, $m=$ Cementation coefficient, $n=$ Saturation capacity and $R_{t}=$ Real resistance.

\subsection{Determination of Hydrocarbon Saturation}

Hydrocarbon saturation $S_{h}$ is the percentage of pore volume in a formation occupied by hydrocarbon. In this study, the hydrocarbon saturation was determined by subtracting the value of water saturation from $100 \%$, as illustrated in the equation below:

$$
S_{h}=\left(100-S_{w}\right) \%
$$

\subsection{Permeability Estimation}

Well $\log$ is one among the methods used to estimate permeability of a reservoir rock. There are two principal log measurements used to estimate permeability, these are resistivity and porosity logs. Porosity log is frequently preferred than resistivity log because it is strongly correlated to permeability [6]. In petrophysics various empirical models were established for permeability estimation, these include model by Tixier [27], Wyllie and Rose [28], Timur [29], Coats and Dumanoir [30], Coats and Denoo [31]. The classification of these models was based on grain size, pore dimensions, mineralogy and surface area, or water saturation [6] [32]. In this study, the Timur [29] model was used to estimate the permeability of each delineated reservoir rocks of Mpapai well. This method depends on porosity and irreducible water saturation as shown in the equation below [23]:

$$
K=0.136 \frac{\phi^{4.4}}{S_{w i r}^{2}}
$$

where $K=$ Permeability in $\mathrm{mD}, \phi=$ Porosity and $S_{w i r}=$ Irreducible water saturation Irreducible water saturation was estimated from Crain's method [33] using the equation below [34]:

$$
S_{\text {wirr }}=\frac{\phi \times S_{w}}{\phi_{\text {eff }}}
$$

where $\phi \times S_{w}$ represents the bulk volume of water (BVW).

The bulk volume of water is used to indicate if the reservoir rock is at irre- 
ducible water saturation or not. If values for bulk volume of water obtained at different depths are constant, they indicate that the reservoir zone is at irreducible water saturation otherwise the reservoir zone is not at irreducible water saturation [12]. Permeability of reservoir rocks is qualitative and the qualitative description used in this study is given in Table 3 (Rider, 1986; Baker, 1992).

\section{Results and Interpretations}

\subsection{Qualitative Interpretation}

\subsubsection{Zones Created and Lithology Interpretation}

Petrophysical analysis of well logs and cross plot reveals that Mpapai well consists of three types of lithology: sand, shale and carbonate (limestone). The well section was divided into four depth intervals with their corresponding log curves for easy description of lithology type. In connection to the four depth intervals used to describe the three types of lithology, the same intervals were used to form four zones that consist of alternating sand and shale formations (Figures 4-7; Table 4). Generally, the stratigraphy of Mpapai well shows the composition of alternating sand and shale layers (Table 4). The thicknesses of shale layers are observed to increase with depth along with a corresponding decrease in sand layer. In some intervals the sandstone formations are cemented by carbonate cement.

\subsubsection{Reservoir Identification}

From the four chosen depth intervals shown in the previous section, seven clean sand bodies were identified across Mpapai well, which were named as MpapaiA, B, C, D, E, F and MpapaiG. Generally, based on visual observation of well logs, zones that showed low gamma ray values, relatively high porosity and high resistivity values were identified as reservoir zones. Therefore, only four sandstone bodies named MpapaiB, E, F and MpapaiG among seven identified zones were marked as reservoir zones (Figure 8 and Figure 9). These zones were also characterized by neutron-density crossover showing wider separation, which indicate the presence of gas.

\subsubsection{Hydrocarbon and Non-Hydrocarbon Bearing Zones}

The neutron-density logs combination and resistivity logs were used for the identification and characterization of various fluids in the reservoir zone. Based on visual observation of these logs four selected reservoir zones named MpapaiB, $\mathrm{E}, \mathrm{F}$ and MpapaiG among seven selected reservoir zones were identified as gas bearing zones. This is due to the presence of neutron-density crossover and

Table 3. Permeability values used in the qualitative description of reservoir rocks (Adapted from [20] [21]).

\begin{tabular}{lccccc}
\hline Average $k$ values $(\mathrm{mD})$ & $1.0-15$ & $15-50$ & $50-250$ & $250-1000$ & $>1000$ \\
\hline Qualitative description & Poor to fair & Moderate & Good & Very Good & Excellent \\
\hline
\end{tabular}


Table 4. Summary of detailed seven sandstone bodies and four reservoir zones identified from gamma ray log.

\begin{tabular}{cccc}
\hline Depth & Sandstone Bodies & Reservoir Zones & Lithology \\
\hline $3003.66-3008.04$ & MpapaiA & & Sand \\
$3014.99-3018.79$ & MpapaiB & MpapaiB & Sand \\
$3079.88-3085.2$ & MpapaiC & & Sand \\
$3119.53-3125.8$ & MpapaiD & & Shaly Sand \\
$3199.37-3235.95$ & MpapaiE & MpapaiE & Shaly Sand \\
$3246.74-3252.29$ & MpapaiF & MpapaiF & Sand \\
$3968.57-4007.26$ & MpapaiG & MpapaiG & Sand \\
\hline
\end{tabular}

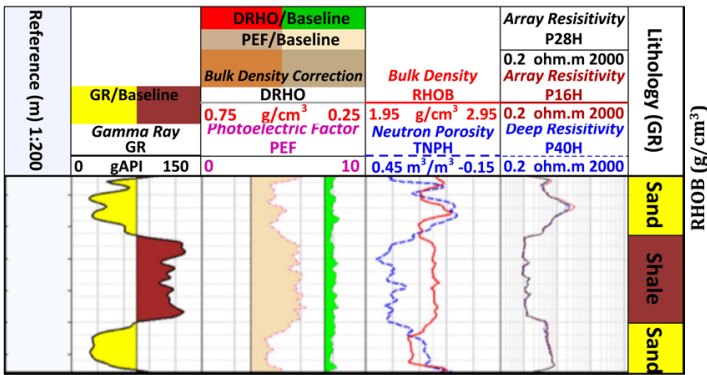

(a)

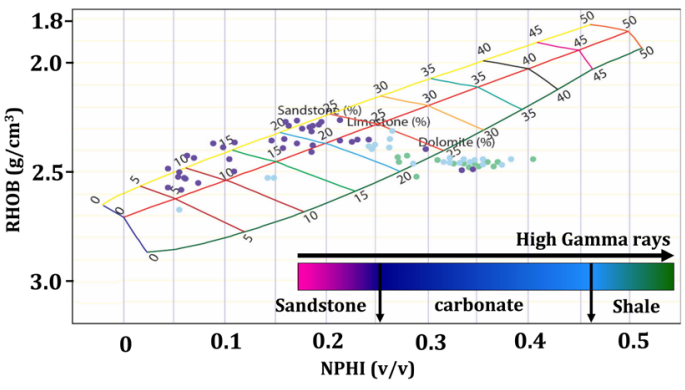

(b)

Figure 4. Type of lithology at depth interval $3003.66 \mathrm{~m}$ to $3018.79 \mathrm{~m}$ from (a) Well log curves (b) Neutron-Density cross plot.

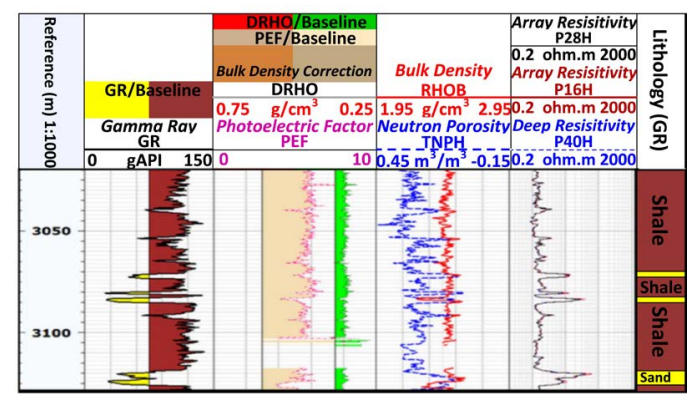

(a)

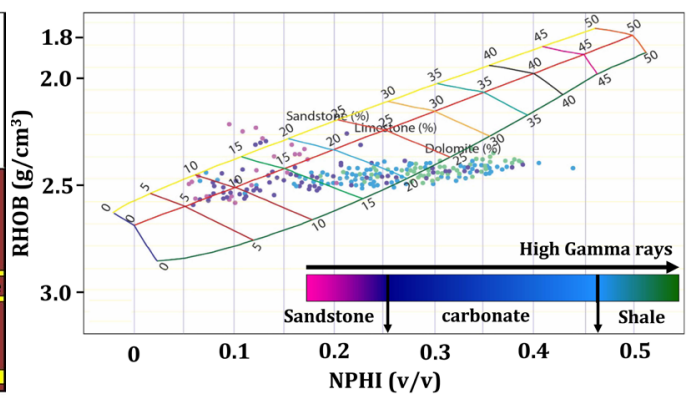

(b)

Figure 5. Type of lithology at depth interval $3018.79 \mathrm{~m}$ to $3125.8 \mathrm{~m}$ from (a) Well log curves (b) Neutron-Density cross plot.

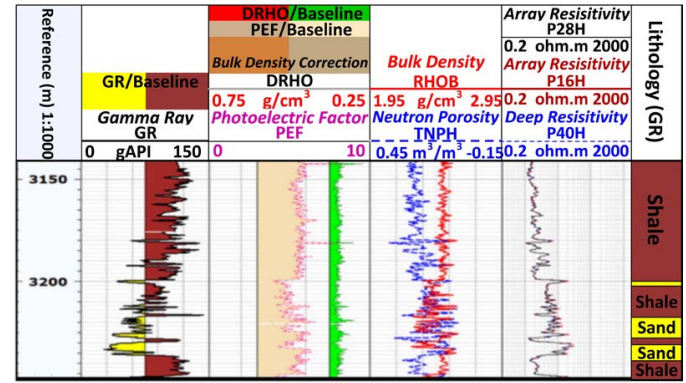

(a)

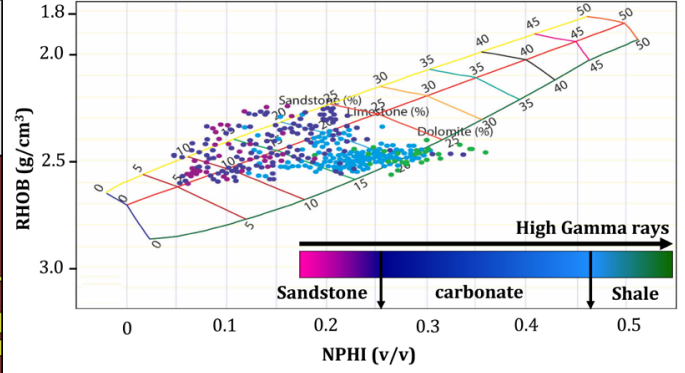

(b)

Figure 6. Type of lithology at depth interval $3125.8 \mathrm{~m}$ to $3246.74 \mathrm{~m}$ from (a) Well log curves (b) Neutron-Density cross plot. 


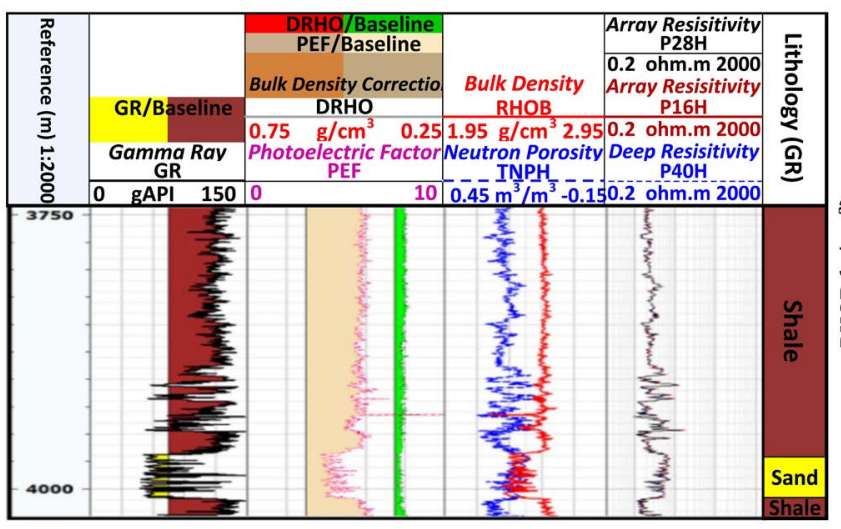

(a)

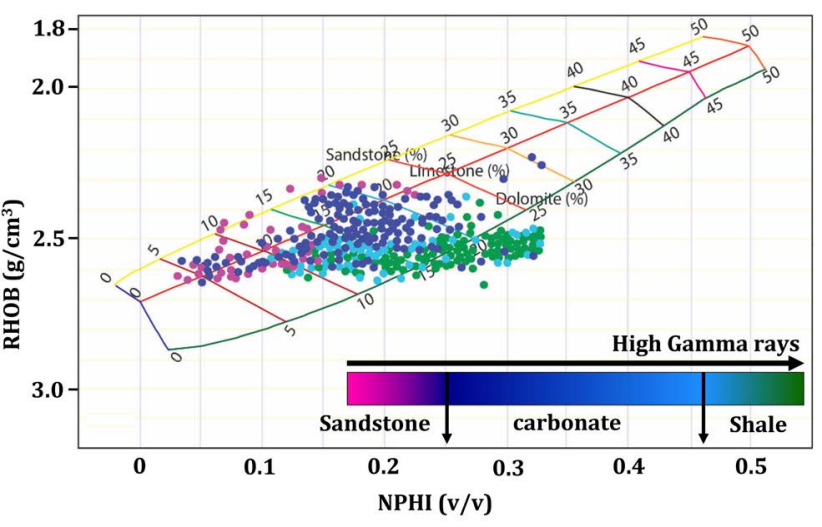

(b)

Figure 7. Type of lithology at depth interval $3750 \mathrm{~m}$ to $4007.26 \mathrm{~m}$ from (a) Well log curves (b) Neutron-Density cross plot.

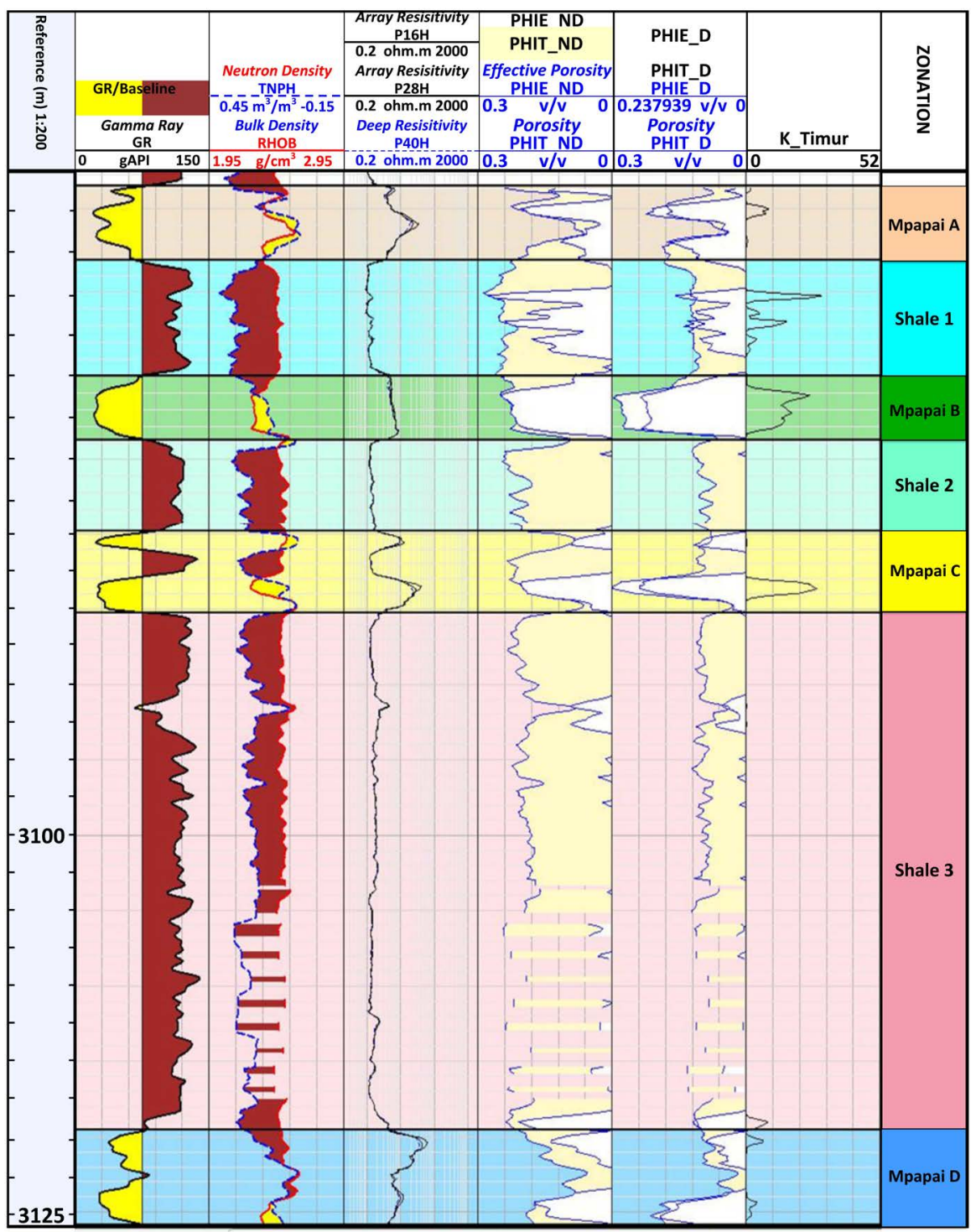

Figure 8. Well log curves showing MpapaiA, MpapaiB, MpapaiC and MpapaiD reservoir zones. 


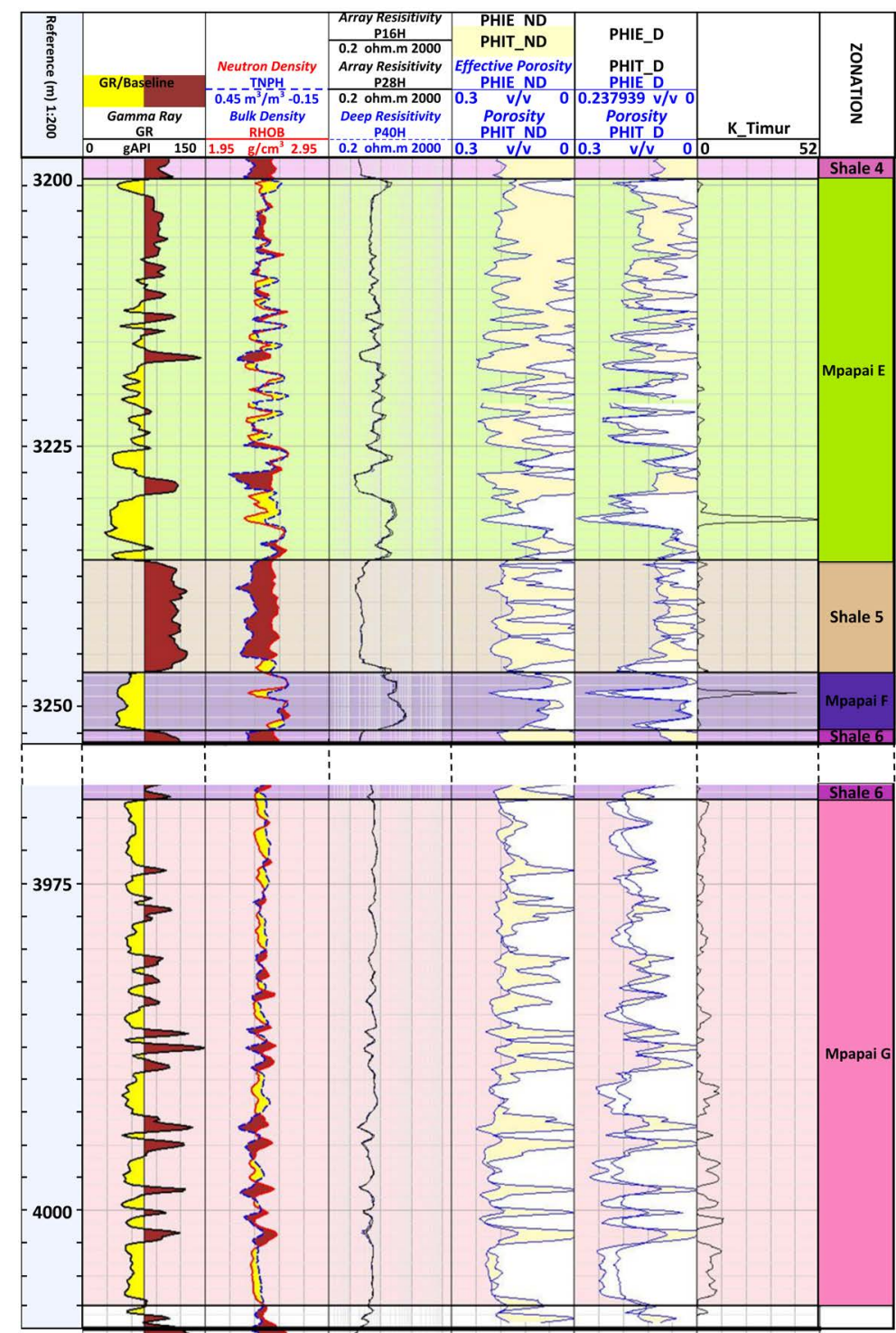

Figure 9. Well log curves showing MpapaiE, MpapaiF and MpapaiG reservoir zones.

high resistivity values. Neutron and density crossover were observed in some intervals and marked by yellow color as shown in the log curves for MpapaiB, E, F and MpapaiG respectively (see Figures 10-13). In resistivity logs, values in the reservoir zones were observed to be relatively higher, which also indicate the presence of hydrocarbon. As described in methodology part, resistivity logs are commonly used to differentiate types of hydrocarbon fluids in the sense that liquid hydrocarbon normally display higher resistivity values compared to gas zones. Based on these observations, the type of hydrocarbon fluid that could be found in these reservoirs is gas.

\subsection{Quantitative Interpretation}

Four reservoir zones have been selected in Mpapai well with average thicknesses ranging from $3.8 \mathrm{~m}$ in MpapaiB to $38.69 \mathrm{~m}$ in MpapaiG. The computed 


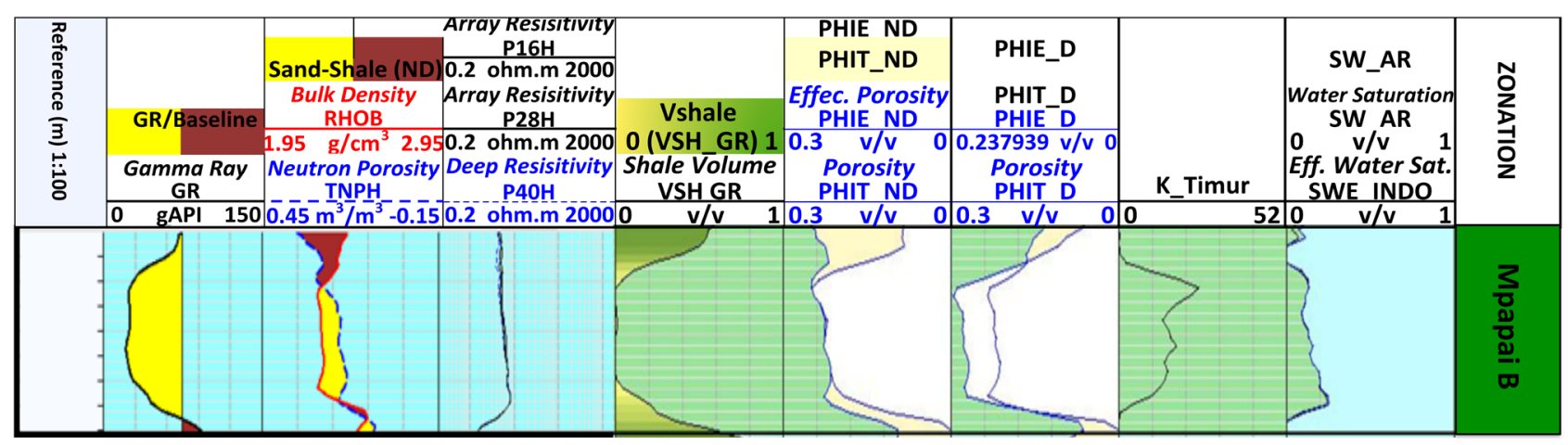

Figure 10. Well log curves showing neutron-density crossover and computed petrophysical parameters for MpapaiB.

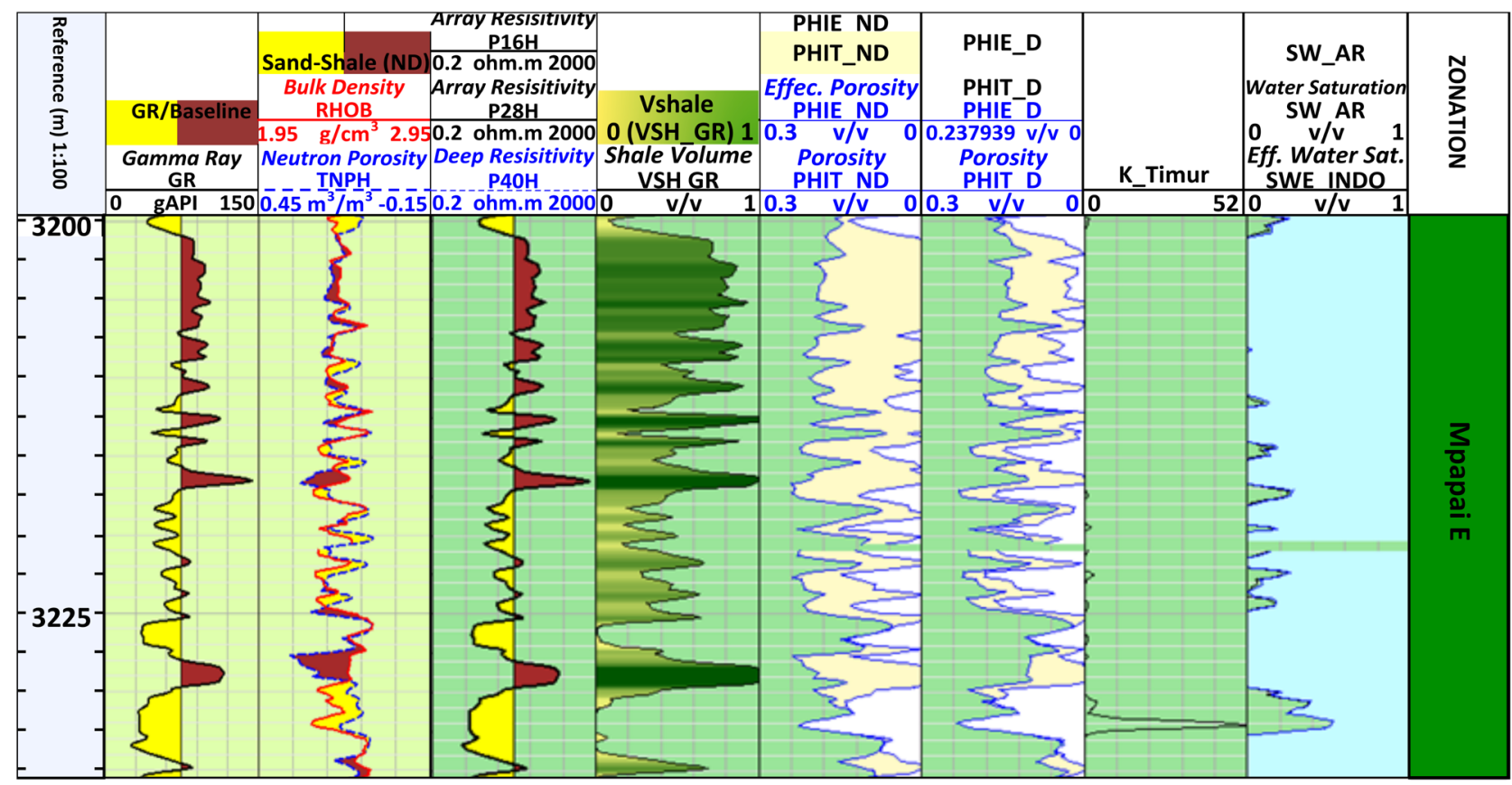

Figure 11. Well log curves showing neutron-density crossover and computed petrophysical parameters for MpapaiE.

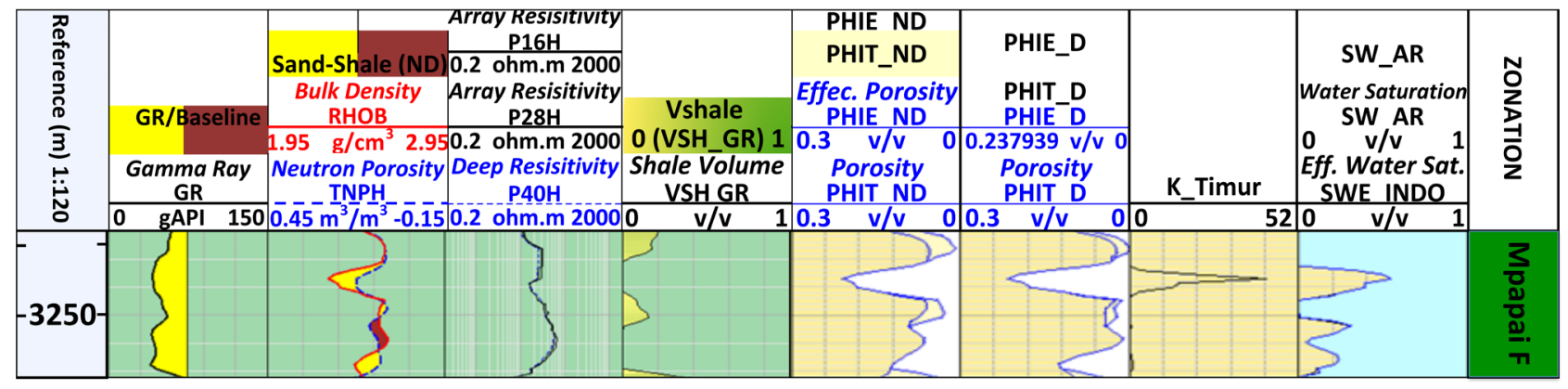

Figure 12. Well log curves showing neutron-density crossover and computed petrophysical parameters for MpapaiF.

average shale volume content of the reservoirs ranges between 0 and $0.079 \mathrm{v} / \mathrm{v}$ (Table 5). The average total and effective porosity derived from neutron and density logs were observed to range from $14 \%$ to $21 \%$ and $8 \%$ to $17 \%$ respectively. The average Indonesian water saturation was observed to be $86.3 \%$, 


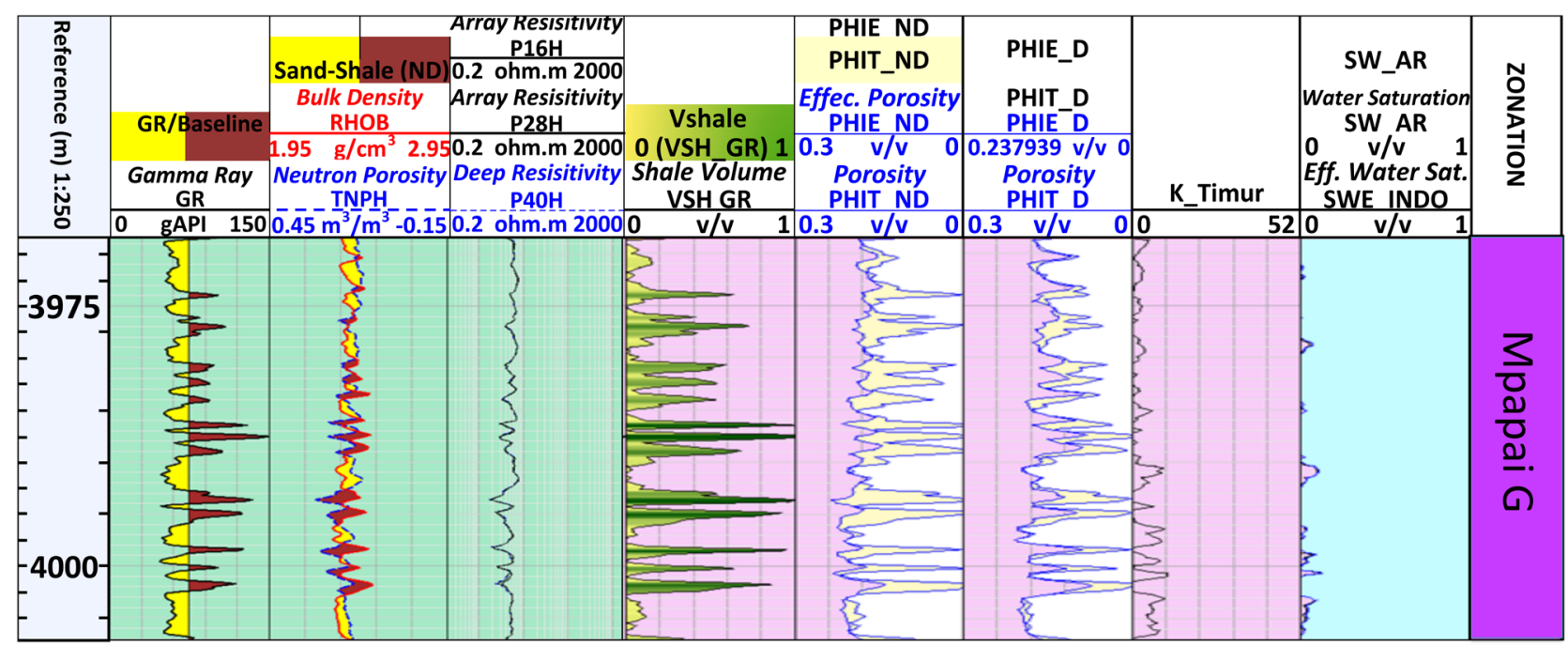

Figure 13. Well log curves showing neutron-density crossover and computed petrophysical parameters for MpapaiG.

Table 5. Summary of sum and averages of computed petrophysical parameters.

\begin{tabular}{|c|c|c|c|c|c|c|c|c|c|c|}
\hline Zones & $\begin{array}{l}\text { Top } \\
\text { (m) }\end{array}$ & $\begin{array}{c}\text { Bottom } \\
\text { (m) }\end{array}$ & $\begin{array}{c}\text { Gross } \\
\text { (m) }\end{array}$ & $\begin{array}{l}\text { Net } \\
(\mathrm{m})\end{array}$ & $\begin{array}{l}\text { NTG } \\
(v / v)\end{array}$ & BVW & $\begin{array}{c}A v-V s h \\
(v / v)\end{array}$ & $\begin{array}{c}\text { Av-Por } \\
\%\end{array}$ & $\begin{array}{c}\mathrm{Av}-\mathrm{Sw} \\
\%\end{array}$ & $\begin{array}{l}\text { Av-K } \\
(\mathrm{mD})\end{array}$ \\
\hline MpapaiB & 3014.99 & 3018.79 & 3.8 & 2.896 & 0.762 & 0.522 & 0.055 & 20.9 & 86.3 & 13.68 \\
\hline MpapaiE & 3199.37 & 3235.95 & 36.58 & 5.181 & 0.143 & 0.552 & 0.077 & 14.2 & 75.3 & 7.068 \\
\hline MpapaiF & 3246.74 & 3252.29 & 5.55 & 1.372 & 0.247 & 0.136 & 0 & 15.5 & 64.1 & 11.16 \\
\hline MpapaiG & 3968.57 & 4007.26 & 38.69 & 26.52 & 0.685 & 4.298 & 0.079 & 16.5 & 98.4 & 3.929 \\
\hline
\end{tabular}

$75.3 \%, 64.1 \%$ and $98.4 \%$ for MpapaiB, E, F and MpapaiG respectively while that of Archie model was observed to be $84.8 \%, 74 \%, 63.2 \%$ and $97.4 \%$ for MpapaiB, E, F and MpapaiG respectively (see Figures 10-13). The water saturation values suggest that reservoir zones are water bearing with low hydrocarbon saturation (1.6\% to $35.9 \%)$. The average permeability was observed to be fair to moderate with average values ranging from $3.9 \mathrm{mD}$ to $11.2 \mathrm{mD}$ (see Table 3; Figures 10-13).

\section{Discussion}

\subsection{Assessment of Petrophysical Parameters from Qualitative Interpretation}

The petrophysical analysis of Mpapai well on identification of lithology indicates that the well consists of three types of lithology, which are shale, sand and very little carbonate. The most dominant lithological unit encountered at Mpapai well was shale formation with thickness ranging from $7 \mathrm{~m}$ to $716 \mathrm{~m}$. These shale units as described in the study by Nicholas et al. [4] forms claystone or muddy clays, which develop a mild shaly parting. Sandstone formation was also identified with thickness ranging from $3.8 \mathrm{~m}$ to $36.58 \mathrm{~m}$ and in some intervals sandstone formation was interbedded with thin shale beds. Anomalous peaks in gamma ray log together with the overlay of neutron and density curves indicate the 
presence of carbonate formation. Neutron-density cross plot strongly show the presence of carbonate formation. In most cases carbonate formation (limestone) occurs as cement in sandstone formation. Stratigraphic log curves show that Mpapai well consists of alternating sand and shale layers. The shale layers were observed to increase with depth along with a corresponding decrease in sand layers.

Based on well log analysis, a total of seven clean sand formations were identified, which were named as MpapaiA, B, C, D, E, F and MpapaiG. Of the seven sandstone bodies, four reservoir zones with high resistivity values and the presence of neutron-density crossover were identified. These include MpapaiB (3.8 $\mathrm{m}$ thick), MpapaiE (36.58 m thick), MpapaiF (5.55 m thick) and MpapaiG (38.69 $\mathrm{m}$ thick). The reason for categorizing the four sand units as different reservoir zones was based on eliminating thick shale beds between reservoirs so as to reduce the effect of increasing shale volume when computing other petrophysical parameters. The shale formation between the identified reservoirs could thus be interpreted as source rock when located below reservoir rock and as a seal rock when located above the reservoir rock.

\subsection{Assessment of Petrophysical Parameters from Quantitative Interpretation}

The four selected reservoir zones were analyzed quantitatively to estimate the values of shale volume, porosity and water saturation by using empirical formulas as described in the methodology part. After applying cutoff values of 0.5 shale volume, $9 \%$ porosity and $50 \%$ of water saturation, the net pay thicknesses for the four selected reservoir zones of MpapaiB, E, F and MpapaiG were found to be 2.90 $\mathrm{m}, 5.18 \mathrm{~m}, 1.37 \mathrm{~m}$ and $26.52 \mathrm{~m}$ respectively (Table 2). The average shale volume estimated from gamma ray $\log$ was found to be $0.055 \mathrm{v} / \mathrm{v}, 0.077 \mathrm{v} / \mathrm{v}, 0 \mathrm{v} / \mathrm{v}$ and $0.079 \mathrm{v} / \mathrm{v}$ for MpapaiB, E, F and MpapaiG respectively (Table 5). Based on these estimates reservoir zones were interpreted as clean sand reservoirs. The total and effective porosity results of the delineated reservoir zones vary widely ranging from $14 \%$ to $21 \%$, which indicate that the reservoir quality ranges from fair to good porosity (e.g., [20] [21]). Saturation results indicate that more than $75 \%$ of Mpapai prospect consists of water in which the average value of water saturation for each reservoir zone was found to be $86.3 \%$ for MpapaiB, 75.3\% for MpapaiE, 64.1\% for MpapaiF and $98.4 \%$ for MpapaiG. The water saturation indicates that the proportion of void space occupied by water is high consequently low hydrocarbon saturation and low hydrocarbon production.

\subsection{Geological Implication on the Petrophysical Parameters}

Generally the quality of reservoir zones of Mpapai well is strongly affected by both local and regional geology of the area. Locally, the East Pande Block is highly composed of clays with very fine grains [4], which tend to fill in open spaces between courser grains (sand particles). This eventually reduces porosity and permeability, which are the key parameters for a good reservoir rock (e.g., 
[20] [21]). The high shale content in the East Pande Block accumulated during period of increased subsidence of the passive margin in Southern coastal Tanzania from Late Cretaceous to Paleogene [4] [11]. The stratigraphic sequence of the East Pande Block shows that during Late Cretaceous there was development of a thick, muddy slope characterized by the presence of long-lived slope valley systems in the architecture of Tanzania. The East Pande Block is also characterized by different fault structures trending in different directions mostly NNW to SSE [8]. These faults have an effect of allowing migration of fluid hence could have contributed on accumulation of water in Mpapai prospect causing high water saturation.

\section{Conclusion}

Generally, by considering all parameters such as reservoir thickness, shale volume, porosity, permeability, water saturation and hydrocarbon saturation from the log analysis performed in this study, the quality of the reservoir sand units of Mpapai well is poor. Some reservoir zones (MpapaiB and F) are very thin, which also reduce the quality of reservoir zones if they do not extend lateral. Selected reservoir zones have an average porosity ranging from fair to good. MpapaiB has good porosity of $21 \%$ while MpapaiE, $\mathrm{F}$ and $\mathrm{G}$ have fair porosity of $14 \%, 15 \%$ and $16 \%$ respectively. Permeability obtained from this analysis is fair indicating that the reservoir sand bodies are impermeable that might have been affected by the geology of the area where high degree of compaction, cementation (presence of carbonate cement in sandstone formation) and high content of clay minerals reduces permeability due to filling in open spaces. The quality of the reservoir zones is also poor due to low hydrocarbon saturation in which more than $75 \%$ of the reservoir zones are filled with water. The water saturation indicates that the proportion of void space occupied by water is high consequently low hydrocarbon saturation and low hydrocarbon production.

\section{Acknowledgements}

The authors are grateful to Statoil Companyin collaboration with the University of Dar es Salaam in Tanzania for funding this research as part of MSc. study. We thank Tanzania Petroleum Development Company (TPDC) for providing the data used in this study. We also thank many individuals from the University of Dar es Salaam and TPDC for their assistance in completion of this work. We also thank anonymous reviewers for helpful comments.

\section{References}

[1] Blunt, G. (1973) Sedimentary Basins of the African Coasts. South and East Coast. Association of African Geological Surveys, 193-231.

[2] Salman, G. and Abdula, I. (1995) Development of the Mozambique and Ruvuma Sedimentary Basins Offshore Mozambique. Sedimentary Geology, 96, 7-41. https://doi.org/10.1016/0037-0738(95)00125-R 
[3] Rabinowitz, P.D., Coffin, M.F. and Falve, Y.D. (1983) The Separation of Madagascar and Africa. Science, 220, 67-69. https://doi.org/10.1126/science.220.4592.67

[4] Nicholas, C.J., Pearson, P.N., Bown, P.R., Jones, T.D., Huber, B.T., Karega, A., Lees, J.A., McMillan, I.K., O’Halloran, A. and Singano, J.M. (2006) Stratigraphy and Sedimentology of the Upper Cretaceous to Paleogene Kilwa Group, Southern Coastal Tanzania. Journal of African Earth Sciences, 45, 431-466. https://doi.org/10.1016/j.jafrearsci.2006.04.003

[5] Serra, O. (1986) Fundamentals of Well-Log Interpretation. 2. The Interpretation of Logging Data, Developments in Petroleum Science. Developments in Petroleum Science, 15B, Elsevier, Amsterdam.

[6] Ellis, D.V. and Singer, J.M. (2008) Well Logging for Earth Scientists. 2nd Edition, Springer, Berlin.

[7] Teixeira, L., Martnez, V. and Chrispin, S. (2009) Tanzania Ultra-Deepwater Exploration. Search and Discovery, No. 10189.

[8] Kent, P.E., Hunt, J.A. and Johnstone, D.W. (1971) Geology and Geophysics of Coastal Sedimentary Basins of Tanzania. Geophys. Paper, Institute of Geological Sciences, London, Vol. 6, 1-101.

[9] Nicholas, C.J., Pearson, P.N., McMillan, I.K., Ditchfield, P.W. and Singano, J.M. (2007) Structural Evolution of Southern Coastal Tanzania since the Jurassic. Journal of African Earth Sciences, 48, 273-297. https://doi.org/10.1016/j.jafrearsci.2007.04.003

[10] Lawver, L.A., Coffin, M.F. and Falvey, D.A. (1992) The Mesozoic Break up of Gondwana. 1 st Indian Ocean Petroleum Seminar, 345-356.

[11] Sansom, P. (2016) Sequence Stratigraphic Scheme for the Jurassic-Neogene of Coastal and Offshore Tanzania. Research to Reserves, 1, 33-37.

[12] Asquith, G.B. and Gibson, C.R. (1982) Basic Well Log Analysis for Geologists. The American Association of Petroleum Geologists (AAPG), Tulsa.

[13] Amigun, J.O. and Odole, A.O. (2013) Petrophysical Properties Evaluation for Reservoir Characterization of SEYI Oil Field (Niger-Delta). International Journal of Innovation and Applied Studies, 3, 765-773.

[14] Crain, E.R. (2016) Visual Analysis Rule for Water Saturation, Petrophysical Handout. https://www.spec2000.net/00-404-redirect.htm

[15] Larionov, V. (1969) Radiometry of Boreholes. NEDRA, Moscow.

[16] Stieber, S. (1970) Pulsed Neutron Capture Log Evaluation-Louisiana Gulf Coast.

[17] Clavier, C., Hoyle, W. and Meunier, D. (1971) Quantitative Interpretation of Thermal Neutron Decay Time Logs: Part I. Fundamentals and Techniques. Journal of Petroleum Technology, 23, 743-755. https://doi.org/10.2118/2658-A-PA

[18] Bassiouni, Z. (1994) Theory, Measurement and Interpretation of Well Logs. Textbook Series, Vol. 4, Society of Petroleum Engineers (SPE).

[19] Said, A., Christoph, M., Stuart, C. and Mohamed, A.M. (2015) Sedimentary Budget of the Tanzania Coastal Basin and Implications for Uplift History of the East African Rift System. Journal of African Earth Sciences, 111, 288-295. https://doi.org/10.1016/j.jafrearsci.2015.08.012

[20] Etnyre, L. (1989) Finding Oil and Gas from Well Logs. Van Nostrand Reinhold, New York. https://doi.org/10.1007/978-1-4757-5230-4

[21] Rider, M. (1986) The Geological Interpretation of Well Logs. Blackie, Glasgow.

[22] Baker, H.I. (1992) Advanced Wireline and MWD Procedures Manual. B.H.I. Tech- 
nical Publications Group.

[23] Tiab, D. and Donaldson, E.C. (2004) Petrophysics Theory and Practice of Measuring of Reservoir Rocks. 2nd Edition, Gulf Professional Publishing, Oxford.

[24] Philip, C.I. (2014) Formation-Resistivity Theory. How Archie Equations, Shaly-Reservoir Models, Conductive Rock-Matric Model and Dual-Triple-Porosity Model Are Related. SPE-167507-PA.

[25] Alimoradil, A., Moradzadeh, A. and Bakhtiari, M.R. (2011) Methods of Water Saturation Estimation. Historical Perspective. Journal of Petroleum and Gas Engineering, 2, 45-53.

[26] Movahed, A. and Mohsen, M. (2015) Determination of Petrophysical Parameters of Ilam Formation in Abteimoor Oilfield. Science Journal, 36, 1618-1623.

[27] Tixier, M.P. (1949) Evaluation of Permeability from Log Resistivity Gradients. Oil and Gas Journal, 48, 113-122.

[28] Wyllie, M. and Rose, W.D. (1950) Some Theoretical Considerations Related to the Quantitative Evaluation of the Physical Characteristics of Reservoir Rock from Electrical Log Data. Transactions of AIME, 189, 105-118.

[29] Timur, A. (1968) An Investigation of Permeability, Porosity and Residual Water Saturation Relationships for Sandstone Reservoirs. The Log Analyst, 9, 3-5.

[30] Coats, G.R. and Dumanoir, J.L. (1974) A New Approach to Improved Log-Derived Permeability. The Log Analyst, 15, 17-31.

[31] Coats, G.R. and Denoo, S. (1981) The Producibility Answer Product. The Technical Review, 29, 55-144.

[32] Mohaghegh, S., Balan, B. and Amerl, S. (1997) Permeability Determination from Well Log Data. SPE Formation Evaluation Journal, 12, 170-174. https://doi.org/10.2118/30978-PA

[33] Crain, E.R. (1986) The Log Analysis Hand Book. Penn-Well, Publ. Co., Tulsa.

[34] Noah, A.Z. and Shazly, T.E. (2014) Intergradation of Well Logging Analysis with Petrophysical Laboratory Measurements for Nukhul Formation at Lagia-8 Well, Sinai, Egypt. American Journal of Research Communication, 2, 139-146. 